Original Article
2018 Journal Impact Factor: 1.10 Print ISSN: 2636-7378 | Online ISSN: 2651-5865

|pg. 324

\title{
Bacteriological and Mycological surveillance of Bed Linens at a Major Tertiary Hospital in North Central Nigeria
}

\author{
Nyinoh IW ${ }^{1}$ Onah OE$^{1}$ Ooja B-E ${ }^{2}$, Liamngee $\mathbf{K}^{1}$ \\ ${ }^{\prime}$ Department of Biological Sciences, Benue State University, \\ Makurdi 970001, Benue State, Nigeria. \\ ${ }^{2}$ Department of Epidemiology and Community Health, Benue \\ State University Teaching Hospital, Makurdi, 970001, Nigeria.
}

\author{
*Correspondence \\ Dr.Iveren Winifred Nyinoh : inyinoh@bsum.edu.ng

\begin{tabular}{|l|l|}
\hline $\begin{array}{l}\text { Article } \\
\text { information }\end{array}$ & $\begin{array}{l}\text { Date Submitted: 2/4/2020. } \\
\text { Date Accepted: 6/6/2020 } \\
\text { Date Published: June, 2020 }\end{array}$ \\
\hline
\end{tabular}

\begin{abstract}
Knowledge of the microbial diversity on hospital bed linens has implicit significance for infection control because bed linens are likely reservoir and vehicles for healthcare-associated Infections (HAIs). In this study, the diversity of microorganisms that persist on bed linens at Benue State University Teaching Hospital (BSUTH), Makurdi, Nigeria was evaluated. Patients' bed and surface areas on bed linens were chosen at random from ten different wards and the swab sampling method employed. Of the 30-bed linens sampled, bacteria were more prevalent at 19 (63.33\%), fungi at $10(33.33 \%)$. We identified both bacteria and fungi from eight wards, only fungi from the antenatal ward and no contamination from the amenity ward, 1(3.33\%). Staphylococcus aureus, Escherichia coli, Klebsiella, and coagulasenegative Staphylococcus dominated the bacterial profile. Similarly, Aspergillus niger, Candida albicans, and Microsporium ferrugenium fungi were also recovered from the bed linens. Amongst the bacteria identified, Escherichia coli gave the highest prevalence at 7(36.84\%), whereas, Candida albicans revealed the highest among the fungi isolates with 5(50\%). Chi-square analysis showed a significant relationship $(\chi 2=68.48, d f=8, P<0.05)$ between the microbial contamination and the wards sampled. The mean bacterial count (cfu/ml) was checked for each ward and the female surgical ward showed the highest count of $31.3 \times 10^{3}$ while the paediatric ward had the least count of $2.3 \times 10^{3}$. Control beddings were also contaminated with $1.3 \times 10^{3}$.These results suggest that the bed linens from the hospital wards were contaminated with pathogenic microbes which can contribute to HAIs.
\end{abstract}

Keywords: Healthcare associated infections (HAIs), Hospital bed linen, Infection control, Microbes

\section{INTRODUCTION}

$\mathrm{H}^{2}$ ealthcare-associated infections (HAIs) are absent in patients at the point of admission; yet occur while receiving medical care in a hospital or healthcare facility. They usually occur within the first 24-hours following admission or 30-days after receiving healthcare. ${ }^{1,2,3}$ HAIs affect several patients from developing and developed countries alike, resulting in extended hospital stay, longterm disability, heightened antimicrobial resistance, increased financial burden and preventable death. ${ }^{4}$ In developing countries, the burden of HAIs is often 
undetermined due to multiplex diagnosis, the dearth of expertise and capital for monitoring, to promote health. ${ }^{5}$ In 2016 and 2017, the European Centre for Disease Prevention and Control coordinated point prevalence studies of HAIs. Data obtained revealed that approximately 8.9 million HAIs occurred in both hospitals and long-term health facilities in the European Union (EU) and European Economic Area (EEA) countries. ${ }^{6}$ In a point prevalence study conducted in US hospitals by CDC and the Emerging Infections Program (EIP), a $3.2 \%$ prevalence of hospitalized patients had HAIs in 2015 , by comparison to $4.0 \%$ in $2011^{7}$, and one out of 25 hospitalized patients had at least one HAIs.

According to the AWMF Working Group for Hygiene in Hospital and Practice ${ }^{8}$ and Ayliffe et al. ${ }^{9}$ the hospital bed, consists of bed rail, bed linen, mattress, and pillows. These components are in direct contact and are routinely touched by patients, health care workers or visitors. ${ }^{10,11}$ The propensity of textiles to foster, sequester and convey microorganisms, from humans to the environment may occur at any time, before, in the course of, and following laundry. ${ }^{12,13}$ With good environmental conditions, these microbes could result in significant public health threats of hospital-acquired infections, if not well disinfected. The sources of microbes on contaminated textile are numerous, including body fluids and tissues for instance skin, vomit, faecal matter, urine, and blood. ${ }^{14}$ Thus, effective laundering is required; first, to remove blemishes, restore appearance, and malodours and to reduce infection risk by lessening the microbial load to safe levels. ${ }^{12,15}$

The hypothesis investigated in this study is that the bed linens at Benue State University Teaching Hospital (BSUTH) are contaminated with several nosocomial pathogens that can cause HAIs. The aim of this study is therefore to; assess the microbial diversity from bed linens from ten wards at the BSUTH, Makurdi.

\section{MATERIALS AND METHODS}

\section{Study Area}

The present study was carried out from May - July 2019 at the BSUTH. Sampling was carried out in ten (10) different wards of the hospital namely; Accident and Emergency (A\&E) male, A\&E female, Male Surgical, Female Surgical, Male Medical, Female Medical, Postnatal, Paediatrics', Antenatal and Amenity wards. Ethical clearance for this study was obtained from the Health Research Ethics Committee, BSUTH.

\section{Culture media}

Sarbouraud dextrose agar (SDA) (Oxoid) and Nutrient agar (HiMedia Laboratories, India) were used in isolating microbes. The media was prepared according to the manufacturers recommended procedure and supplemented with antifungal and antibiotics.

\section{Collection of samples}

A total of 30-bed linens were evaluated for bacterial and fungal contamination. The sampling points include; edge/middle of bed linen, outside and inside bed sheets. Two designated bed linen were used; dirty bed linens (stained with blood, urine or faeces) and clean (unused) bed linens, which served as the control. Samples were collected with the aid of swab sticks. This was achieved by rubbing a swab stick already moistened with normal saline on the surface of the bed linen as described. ${ }^{16}$ The swabs were put into sterile test tubes, closed tightly and labelled appropriately. Samples were immediately transported to the Evidence medical and research laboratory, Makurdi for analysis.

\section{Isolation and identification of microorganism from bed linens}

The contaminated swab sticks were used to inoculate nutrient agar plates for bacteria growth. Incubation was at $37^{\circ} \mathrm{C}$ for 24 hours in a DNP-9052A, Easy way Medical England, incubator. For the identification of fungi, swab sticks were used to inoculate SDA agar plates and incubated at $25^{\circ} \mathrm{C}$ for 3-4 days. Identification of fungi was achieved by comparing the morphological characteristics as described ${ }^{17}$, whereas bacteria identification was done using Bergey's Manual of Determinative Bacteriology as reported. ${ }^{18}$

\section{laboratory tests}

The laboratory procedures were performed on the bacterial isolates:

\section{Motility test}

A semisolid motility test was used. The medium was stabbed with a small amount of bacteria inoculum using a sterile needle and incubated overnight at room temperature. If the bacteria species is motile, the medium 
growths spread out from the line of inoculum but if not motile, only the stab line has visible bacterial growth. ${ }^{18}$

\section{Catalase test}

A 24-hour old culture was used to make a smear on a clean slide, and 3\% hydrogen peroxide was added in drops. Production of gas indicates a positive reaction while a negative reaction shows no gas or bubbles. This test was done to determine the presence of enzyme catalase possibly produced by the isolates. ${ }^{19}$

\section{Gram's staining}

A heat-fixed smear from 24-hour old bacterial isolates was prepared, stained with crystal violet, flooded with Gram's iodine, and decolourized with $70 \%$ alcohol solution. This was rinsed under running water and flooded with Safranin $\mathrm{O}$ stain. The slides were then washed under clean water and examined under the microscope using the oil immersion objective (x100). The staining technique also shows the shapes and arrangement of bacterial isolates. ${ }^{19}$

\section{Coagulase test}

A drop of distilled water was placed on each end of a clean grease-free slide with the aid of a sterile inoculating loop; a colony of the test organism was picked using a sterile inoculating loop and the colony was emulsified on the drop of distilled water. An inoculation loop was used to add a loopful of plasma suspension and was checked for the clumping of organisms. No plasma was added to the second suspension; thus, this is used to differentiate any granular appearance of the organism from true coagulase clumping. Clumping of the organism indicates a positive result, while no clumping indicates a negative result. ${ }^{18}$

\section{Indole test}

About $10 \mathrm{ml}$ of peptone water was aliquoted into a test tube; with the aid of a sterile loop, a small colony of the isolate was inoculated into the peptone water. The test tube was incubated at $37^{\circ} \mathrm{C}$ for 24 hours, and a drop of Kovac's reagent was added whilst observing for any reaction. Red colouration of the lower part of the strip confirms the organism as being positive to the indole test. ${ }^{18}$

\section{Germ tube test for the confirmation of Yeast}

About $0.5-1 \mathrm{ml}$ of human serum was pipette into a test tube inoculated with a small colony of the yeast and incubated for 2-3 hours. Microscopic examination was done by placing a small colony onto a glass slide stained with Lactophenol in cotton blue and viewing under the $\times 40$ of the compound microscope. A tube-like outgrowth from sprouting cells was used to confirm the identification of Candida albicans. ${ }^{18}$

\section{Mean bacterial count of bacteria isolates}

The total viable count was estimated using the pour plate method as reported. ${ }^{16}$ Swab samples were initially soaked properly in $1 \mathrm{ml}$ of $0.1 \%$ peptone water, and 10 -fold dilution made. A $1 \mathrm{ml}$ aliquot was inoculated on prepared nutrient agar plates and incubated at $37^{\circ} \mathrm{C}$ for 24 hours. The average counts of the colonies of 30 to 300 were used to obtain the total viable bacterial count of the sample.

\section{Data Analysis}

Data obtained was analysed using Microsoft Excel version 16. The data was first subjected to descriptive statistics (frequency and percentages), and then Chi-square analysis was applied to test for the relationship in microbial rate and the sampled wards.

\section{RESULTS}

We tested three-bed linens per ward to ascertain the bacterial and fungal contamination if any, and the load (cfu/ml). Of the 30 sampled bed linens, 19 were positive for bacteria, 10 for fungi and 1 had no microbe. The distribution of bacteria and fungi in the ten wards is as

Table 1: Percentage contamination frequency of bacteria and fungi on bed linen at BSUTH

\begin{tabular}{lcc}
\hline \multicolumn{1}{c}{ Wards } & Bacteria (\%) & Fungi (\%) \\
\hline A\&E male & $3(15.78)$ & $2(20)$ \\
A\&E female & $1(5.26)$ & $2(20)$ \\
Male surgical & $3(15.78)$ & $2(20)$ \\
Female surgical & $1(5.26)$ & $1(10)$ \\
Male medical & $3(15.78)$ & $1(10)$ \\
Female medical & $4(21.05)$ & $1(10)$ \\
Postnatal & $210.53)$ & 0 \\
Pediatrics & $2(10.53)$ & 0 \\
Antenatal & 0 & $1(10)$ \\
Amenity & 0 & 0 \\
\hline Total & $\mathbf{1 9}(\mathbf{1 0 0})$ & $\mathbf{1 0}(\mathbf{1 0 0})$ \\
\hline
\end{tabular}


shown (Table 1).

The results from our study show that all the four bacteria were isolated from the female medical ward, resulting in a percentage occurrence of 4(21.05). Data in Table 1 reveal that the A\&E male ward, male surgical, and male medical all showed three bacterial contaminants 3(15.78). Correspondingly, the A\&E male ward, A\&E female ward, and male surgical had the highest fungal occurrence at 2(20). With one bacterium identified, the A\&E female and female surgical wards showed the least percentage occurrence, 1(5.26). While only one fungus was isolated in the female surgical, male medical, female medical, and antenatal wards with a percentage occurrence of $1(10)$. We recovered only C. Albicans on the bed linen 1(10) from the antenatal ward and no bacteria were isolated. Amenity wards showed no microbial contamination.

The bacteriological profile of BSUTH bed linens was further differentiated based on morphological characteristics, and biochemical tests were also performed, using the procedure described in the Materials and Methods section. The results are displayed in Table 2. As depicted in Table 2 and Figure 1, the identified bacteria from our study were divided equally between Grampositive ( $S$. aurues and Coagulase-negative staphylococcus) and Gram-negative bacteria (E. coli and

Table 2. Bacterial diversity in the sampled wards as characterized using cultural, morphological and biochemical characteristics of isolated bacteria

\begin{tabular}{lllll}
\hline Cultural characteristics & $\begin{array}{l}\text { Staphylococcus } \\
\text { aureus }\end{array}$ & $\begin{array}{l}\text { Escherichia } \\
\text { coli }\end{array}$ & Klebsiella & $\begin{array}{l}\text { Coagulase -negative } \\
\text { Staphylococcus }\end{array}$ \\
\hline Shape & Circular & Rod & Circular & Circular \\
Colour & White & Milky & Cream & White \\
Size & Large & Small & Large & Large \\
Elevation & Flat & Raised & Raised & Flat \\
Transparency & Opaque & Translucent & Translucent & Opaque \\
Morphological characteristics & & & & + \\
\hline Gram stain & + & rods & Rod & Cocci \\
Cell types & Cocci & clusters & Single & Chains \\
Cell arrangement & Chains & - & - & - \\
Spore staining & - & & & + \\
Biochemical test & & + & + & - \\
\hline Catalase & + & + & + & - \\
Motility & - & - & - & - \\
Indole & - & & & + \\
Coagulase & + & & & - \\
\hline
\end{tabular}

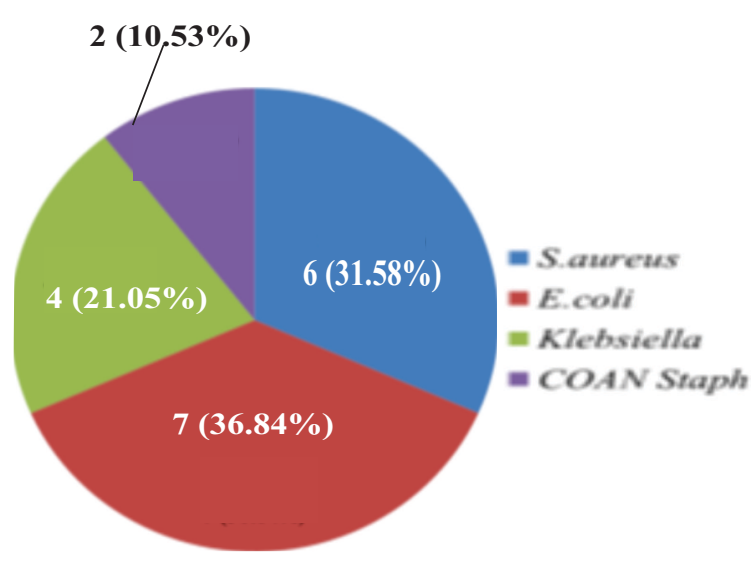

Figure 1: Percentage occurrence of bacterial isolates on used hospital bed linen
Klebsiella sp.).

Next, the percentage occurrence of bacteria isolates from bed linen identified across the wards was analyzed, as shown (Figure 1).

As presented (Figure 1), E. coli had the highest percentage occurrence at 7(36.84), followed by $S$. aureus 6(31.58), Klebsiella sp. 4(21.05) and coagulase-negative Staphylococcus 2(10.53).

The mean bacterial count in the wards sampled was investigated and the results are presented in Table 3.

From our study, A\&E male showed the mean bacterial count of $23.3 \times 10^{3} \mathrm{cfu} / \mathrm{ml}$, A\&E female had a mean bacterial count of $2.6 \times 10^{3}$, the male surgical ward had a mean bacterial count of $7.0 \times 10^{3}$, the female surgical ward had a bacterial count of $31.3 \times 10^{3}$, the male medical ward had a bacterial count of $24.8 \times 10^{3}$, the female medical ward 
had a bacterial count of $6.0 \times 10^{3}$, the post-natal ward had a bacterial count of $10.7 \times 10^{3}$, the paediatric ward had a bacterial count of $2.3 \times 10^{3}$. Both the antenatal and amenity ward had no bacteria growth. From the table, it is obvious that the female surgical ward had the highest mean bacterial count of $31.3 \times 10^{3}$ while paediatrics had the lowest mean bacterial count of $2.3 \times 10^{3}$. The contamination of unused bed linen though very low $\left(1.3 \times 10^{3}\right)$ was unexpected. Chi-square test shows a significant difference between the bed linen across the wards and the clean bed linen, as the $p$-value is less than

Table 3. Mean bacterial count in the wards sampled

\begin{tabular}{|c|c|}
\hline Wards & Bacterial count $\left(\times 10^{3}\right) \mathrm{cfu} / \mathrm{ml}$ \\
\hline Accident and emergency male & 23.3 \\
\hline Accident and emergency female & 2.6 \\
\hline Male surgical & 7.0 \\
\hline Female surgical & 31.3 \\
\hline Male medical & 24.8 \\
\hline Female medical & 6.0 \\
\hline Postnatal & 10.7 \\
\hline Paediatrics & 2.3 \\
\hline Antenatal & Nil \\
\hline Amenity & Nil \\
\hline Control & 1.3 \\
\hline
\end{tabular}

$\chi^{2}=68.48, d f=8, P<0.05$

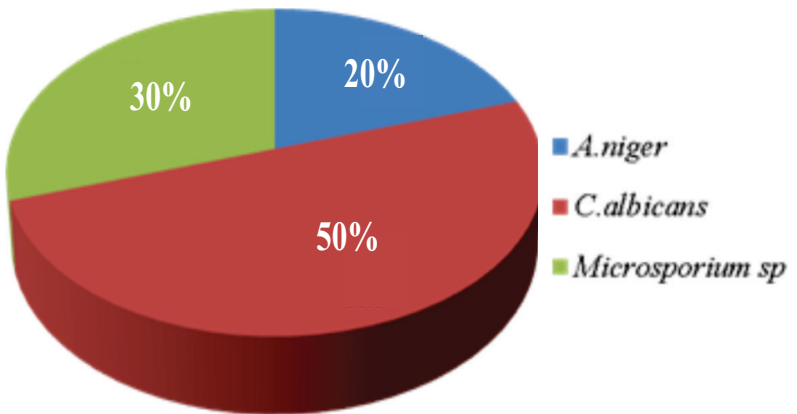

Figure 2: Mycological profile and percentage occurrence of fungal isolates on used hospital bed linen

0.05 .

Data obtained from this pilot study confirm the mycological profile on bed linens at BSUTH as A. niger, C. albicans, M. ferrugineum (Figure 2).

As indicated, three (3) fungal species were isolated. The bed linens tested positive for C. albicans, the most dominant fungi with an occurrence of 5(50). This was followed by Microsporium ferrugineum with 3(30) and Aspergillus niger with 2(20).

\section{DISCUSSION}

To our knowledge, this is the first study undertaken to survey bacterial and fungal contaminants on bed linens at the BSUTH. The reason why we choose this hospital was that; it is a busy hospital catering for large numbers of patients' inter-and-intra-state, multiple admissions occur daily resulting in the use of several reusable bed linens. Microbes are brought into hospitals from phones, shoes, clothing, and skin. ${ }^{13}$ This gives rise to situations where the transfer of microbes by humans to the bed linens can arise by contact with surfaces or airborne. In some hospitals, bed linens are not regularly/properly washed or changed. Thus, the continuous shedding of bacteria may contaminate them. From our study, bed linens from eight of the ten sampled wards were contaminated with both bacteria and fungi. The antenatal ward provides individualized care to women admitted during their pregnancy, and our study identified only one fungal contaminant. Amenity ward is a private ward, and medical care is provided to patients at extra costs; thus, extra hygienic practices are put in place. We found none of the bed linens were contaminated, and this may be due to reduced human traffic.

It is well documented that bed linens contribute to hospital infections. As shown in our study, we identified both Gram-positive and Gram-negative bacteria. Interestingly, the bacteria obtained from these studies are consistent with the results from other studies ${ }^{20,21,22}$ indicating a wider problem in hospitals and medical facilities. Studies by Borkow et al. ${ }^{10}$ have also demonstrated that contaminated bed linens and other non-uniform textiles were implicated as potential sources for the spread of nosocomial-related pathogens, while pyjamas and bed sheets were exposed as a key source of nosocomial pathogens in indoor air. ${ }^{23} \mathrm{We}$ identified three fungi $A$. niger, $C$. albicans and $M$. ferrugenium (Figure 2). Our findings are in agreement with studies by Kordbacheh et al. ${ }^{24}$ carried out at a Tertiary Hospital in Tehran, Iran. Candida albicans, and Aspergillus niger, were isolated, in addition to Penicillium sp., and Cladosporiumsp. C. albicans, the commonest of the Candida species, is a member of the gut, vaginal and gastrointestinal microbiota in humans, and is an 
opportunistic fungus, causing disease in individuals with a weakened immune system. ${ }^{25,26,27}$ It forms the normal microbiota of the mouth, vagina and gastrointestinal tract. Microsporum ferrugineum, a dermatophyte causes Tinea capitis, a fungal infection of the scalp and hair in children, popularly called ringworm. ${ }^{28}$ Infection can be obtained from clothing and bedding, including furniture, toys, combs, telephone, soil or spread from a localized infection. ${ }^{29,30,31}$ Though reports of M. ferrugineum isolated from hospital bed linens are rare, it was not entirely surprising to have identified the fungus. The fungus is endemic in Southeast Asian and African countries like Nigeria, ${ }^{32,33}$ because these countries are characterized by tropical and sub-tropical climates. ${ }^{31} A$. niger has been reported to be the commonest mold found in the environment globally. ${ }^{34}$ However, few cases of cutaneous disease and pulmonary infections can occur in immunocompromised patients. ${ }^{35}$ Data obtained from Dart and Obendorf, ${ }^{36}$ suggests that spores obtained from Aspergillus are readily transmitted by cotton clothes, worn by patients and visitors, by comparison to other fabrics. The bed linens in this study were made of cotton fabric. Diba and colleagues also reported that A. niger and Candida spp. were among the species isolated from bed and blankets. ${ }^{37}$ So as studies by ${ }^{15}$ that reported Staphylococcus and Candida as organisms that contaminate textiles. Some of the organisms isolated in this study are part of the normal human microbiota and can be transferred during handling or wearing, while others such as Aspergillus could have been environmental isolates.

For the mean bacterial counts $(\mathrm{CFU} / \mathrm{ml})$ in the wards sampled, the paediatric ward showed the least $\mathrm{CFU}$ count $\left(2.3 \times 10^{3}\right)$ while the female surgical showed the greatest count $\left(31.3 \times 10^{3}\right)$. Control bed linens had $1.3 \times 10^{3}$ bacteria present, which was rather unexpected. Previous studies did not report any microbial contamination on unused textiles. ${ }^{23,38}$ At present, the level of bacterial contamination resulting in HAIs is unknown. ${ }^{39}$ Thus, we cannot speculate on whether the contamination of bed linens as obtained in this study resulted in any infections.

\section{CONCLUSION}

The results obtained from the study, therefore, suggest that the bed linens from the hospital wards at BSUTH were contaminated with pathogenic microbes. These may serve as a vehicle causing nosocomial infections in patients, especially in those with a weakened immune system, thus raising concerns for infection control. To our knowledge, there are no cleaning and changing policies or set standards for assessing bed linens at BSUTH.

\section{Recommendation}

We recommend proactive measures to ensure BSUTH is keeping nosocomial infections at bay.

\section{Limitation}

We acknowledge the small sample size of this pilot study and recommend further research and molecular testing of the pathogens. Data obtained from this study should be interpreted with caution in the context of its limitations, as such, we cannot comment on the possibility of the contamination resulting in any infections.

\section{Acknowledgment}

The authors would like to thank the staff of Evidence Medical Laboratories, Makurdi particularly Dr. Abba Paul Ojor and Mr. Shima Joseph for their excellent technical support in sample collection and the identification of microbes. We thank the hospital management and staff of BSUTH where the samples were collected, for their cooperation.

\section{Conflict of Interest}

The authors declare that there is no conflict of interest'.

\section{REFERENCES}

1. Haque M, Sartelli M, Mckimm J, Abu Bakar M. Health care-associated infections - an overview. Infect Drug Resist. 2018; 11: 2321-2333. Available from: doi: 10.2147/IDR.S177247.

2. Khan HA, Baig KF, Mehboob R. Nosocomial infections: Epidemiology, prevention, control and surveillance. Asian Pacific Journal of Tropical Biomedicine 2017; 7 (5): 478-482. Available from: doi.org/10.1016/j.apjtb.2017.01.019.

3. Revelas A. Healthcare - associated infections: A public health problem. Niger Med J. 2012; 53(2): 59-64. Available from: doi: 10.4103/03001652.103543 .

4. Allegranzi B, Nejad SB, Combescure C, Graafmans W, Attar H, Donaldson L, et al. Burden of endemic health-care-associated infection in developing 
countries: systematic review and meta-analysis. Lancet 2011; 377(9761): 228-41.

5. Allegranzi B, Pittet D. Preventing infections acquired during health-care delivery. Lancet 2008; 372: 1719-20. Available from: doi: 10.1016/S01406736(08)61715-8.

6. European Centre for Disease Prevention and Control (ECDC). Infographic: Healthcareassociated infections - a threat to patient safety in Europe, No. 2018. Available from:

https://www.ecdc.europa.eu/en/publicationsdata/infographic-healthcare-associated-infectionsthreat-patient-safety-europe.

7. Magill SS, O'Leary E, Janelle SJ, Thompson DL, Ghinwa Dumyati G, Nadle J, et al. Changes in Prevalence of Health Care-Associated Infections in U.S. Hospitals. N Engl J Med. 2018; 379:17321744. Available from: doi: 10.1056/NEJMoa1801550.

8. AWMF Working Group for Hygiene in Hospital and Practice. Hygienic processing of hospital beds. Krankenhaushygiene, Hygiene in hospital and practice, 3rd ed. Wiesbaden: MHP- Verlag; 2005.

9. Ayliffe GAJ, Fraise AP, Geddes AM, Mitchell K. Control of hospital infection. A practical handbook. London: Arnold; 2000.

10. Borkow G, Gabbay J. Biocidal textiles can help fight nosocomial infections. Medical Hypotheses 2008; 70:990-4.

11. Facciola A, Pellicano GF, Visalli G, Paolucci IA, Venanzi Rullo E, Ceccarelli M, et al. The role of the hospital environment in the healthcare-associated infections: a general review of the literature. European Review for Medical and Pharmacological Sciences 2019; 23: 1266-1278.

12. Bloomfield S, Exner M, Flemming HC, GoroncyBermes P, Hartemann P, Heeg P, et al. Lesserknown or hidden reservoirs of infection and implications for adequate prevention strategies: Where to look and what to look for. GMS Hyg Infect Control 2015; 10:Doc04. Available from: doi: 10.3205/dgkh000247.

13. Dawson P, Han I, Cox M, Black C, Simmons L. Residence time and food contact time effects on transfer of Salmonella typhimurium from tile, wood and carpet: testing the five-second rule. J Appl Microbiol. 2007; 102:945-953. Available from doi:10.1111/j.1365-2672.2006.03171.x17381737.

14. Sehulster LM, Chinn RYW, Arduino MJ, Carpenter J, Donlan R, Ashford D, et al. Guidelines for Environmental Infection Control in Health-Care Facilities. Recommendations from CDC and the Healthcare Infection Control Practices Advisory Committee (HICPAC) American Society for Healthcare Engineering/American Hospital Association. Chicago, IL, USA; 2004.

15. Bockmühl DP, Schages J, Rehberg L. Laundry and textile hygiene in healthcare and beyond. Microb Cell 2019; 6(7): 299 - 306. Available from doi: 10.15698/mic2019.07.682.

16. Olise CC, Simon-Oke IA. Fomites: Possible vehicle for nosocomial infections. Journal of Public Health Catalog 2018; 1(1): 11-16. Available from doi: 10.35841/public-health-nutrition.1.1.11-16.

17. Barnett HL, Hunter BB. Illustrated Genera of Imperfect Fungi. Burgess, Minnesota, 3rd ed, 1972; 273.

18. Cheesbrough M. District Laboratory practices in tropical countries, 2000. Cambridge press UK. Pp 35-70.

19. Acharya T. Overview of Biochemical tests used to identify bacteria in Microbiology Laboratory, 2013. Available from:

https://www.microbeonline.com/overview-ofbiochemical-tests-used-to-identify-bacteria-inmicrobiology-laboratory/.

20. Fijan S, Šostar-Turk S, Cencič A. Implementing hygiene monitoring systems in hospital laundries in order to reduce microbial contamination of hospital textiles. J. Hosp. Infect. 2005; 61:30-38. Available from doi: 10.1016/j.jhin.2005.02.005.

21. Okareh OT. Bacterial pathogens from bed linen used in secondary and tertiary health facilities in Benin city, Nigeria. J Microbiol Exp. 2018; 6(2): 84-87. Available from doi: 10.15406/jmen.2018.06.00192.

22. Pinon A, Gachet J, Alexandre V, Decherf S, Vialette M. Microbiological Contamination of Bed Linen and Staff Uniforms in a Hospital. Advances in Microbiology 2013; 3: 515-519.

23. Malnick S, Bardenstein, R, Huzar, M, Gabbay, J, Borkow, G. Pajamas and sheets as a potential source of nosocomial pathogens. The Hospital Infection Society 2008; 70:89-92. 
24. Kordbacheh P, Zaini F, Kamali P, Ansari K, Safara M. Study on the Sources of Nosocomial Fungal Infections at Intensive Care Unit and Transplant Wards at a Teaching Hospital in Tehran. Iranian Journal of Public Health 2005; 34(2).

25. Garber G. An overview of fungal infections. Drugs 2001;61 Suppl 1:1-12.

26. Hay RJ. Fungal Infections In: Farrar J, Hotez P, Junghanss T, Kang G, Lallo D, White N. Manson's Tropical Infectious Diseases. Saunders Ltd; 2014. Pp 441-458.e2.

27. Witchley JN, Penumetcha P, Abon NV, Woolford CA, Mitchell AP, Noble SM. Candida albicans Morphogenesis Programs Control the Balance between Gut Commensalism and Invasive Infection. Cell Host Microbe 2019; 25 (3): 432-443. Available from: doi: 10.1016/j.chom.2019.02.008

28. Mayser P, Nenoff P, Reinel D, Abeck D, Brasch J, Daeschlein G, Effendy I, Ginter-Hanselmayer G, Graser Y, Hipla U, Hoger P, Kolb-Maurer A, Ott H, Schaller M, Zidane M. S1 guidelines: Tinea capitis. Journal of the German Society of Dermatology 2020; 18 (2): 161-179. Available from: https://doi.org/10.1111/ddg.14026.

29. Alakloby OM, Randhawa MA. An outbreak of tinea capitis and its management. Journal of Saudi Society of Dermatology and Dermatological Surgery 2009; 13(1).

30. Patel GA, Schwartz RA. Tinea capitis: still an unsolved problem? Mycoses. 2011; 54(3):183-8. Available from: doi: 10.1111/j.14390507.2009.01819.

31. Raina D, Gupta P, Khanduri A. A First case of Microsporum ferrugineum causing tinea corporis in Uttarakhand, 2016, 9 (5): 351-353. Available from: 10.4103/1755-6783.190195.

32. Rippon JW. Medical Mycology, 3 rd ed. WB Saunders, Philadelphia. 1988.

33. Wisuthsarewong W, Chaiprasert A, Viravan S. Outbreak of tinea capitis caused by Microsporum ferrugineum in Thailand. Mycopathologia 1996; 135:157-61.

34. Schuster E, Dunn-Coleman N, Frisvad J, van Dijck. On the safety of Aspergillus niger - a review. Applied Microbiology and Biotechnology 2002; 59: 426-435.
35. Loudon KW, Coke AP, Burnie JP, Shaw AJ, Oppenheim BA, Morris CQ. Kitchens as a source of Aspergillus niger infection. J Hosp Infect. 1996; 32: 191-198.

36. Dart B, Obendorf S. Retention of Aspergillus Niger Spores on Textiles. In: Nelson C, Henry N, ed. Performance of Protective Clothing: Issues and Priorities for the 21st Century, Seventh Volume. West Conshohocken, PA: ASTM International, 2000), 251-268.

37. Diba K, Rahimirad MH, Makhdoomi KH, Eslamloo NF. Aspergillus Monitoring project in a Large Educational hospital using molecular assay. Afr. J. Infect. Dis. 2014; 8(1): 1 - 4.

38. Burden M, Cervantes L, Weed D, Keniston A, Price CS, Albert RK, "Newly Cleaned Physician Uniforms and Infrequently Washed White Coats Have Similar Rates of Bacterial Contamination after an 8Hour Workday: A Randomized Controlled Trial. Journal of Hospital Medicine 2011;6(4):177-182.

39. Dancer SJ. How do we assess hospital cleaning? A proposal for microbiological standards for surface hygiene in hospitals. J Hosp Infect. 2004; 56:10-15. 